\title{
Sociologist Janet Wolf is A Perfect Example of the Importance of the Place of Women in Society
}

\author{
Sara Sanad Ahmed Sanad \\ Department of Philosophy, Girls College, Ain-Shams University, Cairo, Egypt \\ Email address: \\ sasosara720@gmail.com \\ To cite this article: \\ Sara Sanad Ahmed Sanad. Sociologist Janet Wolf is A Perfect Example of the Importance of the Place of Women in Society. International \\ Journal of European Studies. Vol. 5, No. 1, 2021, pp. 23-30. doi: 10.11648/j.ijes.20210501.13
}

Received: April 28, 2021; Accepted: May 25, 2021; Published: June 16, 2021

\begin{abstract}
In this article, we learn about the sociologist Janet and her synthesis with aesthetics and feminism by getting to know her biography, where she grew up, what positions she held, and what are the most important books she wrote, then we talk about the intellectual trends that were influenced by Wolf, such as the direction of feminist philosophy that was established in order to liberate women from the power of men, and we get to know On the three waves and trends of feminism and what direction Woolf adopted in her writings, then we turn to the postmodern trend and explain the difference between postmodernism and modernity, and whether postmodernism is a continuation of modernity or a rejection of it. That we came up with.
\end{abstract}

Keywords: Feminist Philosophy, Radical Feminism, Gender, Postmodernism, Feminist Aesthetics, Sociology of Art

\section{Introduction}

In this article we are talking about the sociologist and feminist researcher Janet Wolf. She has written in the fields of sociology, arts, culture, and feminism and has authored seven books in the fields of fine arts, sociology, and feminist aesthetics. Woolf tried to reconcile her studies of social science with feminism in order to formulate a social theory that plays Women have a major role in them. Woolf called for the necessity of sharing men with women for the sake of a better society. In this article we also review the intellectual currents that were influenced by Woolf in the presentation of her ideas. They were influenced by three trends, namely, feminist philosophy (which appeared in order to reject masculine centralism and resistance Patriarchy), as I was influenced by Marxism and its talk about the social history of art, and also influenced by the postmodern trend, and that art is a simulation of reality.

\section{Biography of Janet Wolff}

Janet Wolff was born on 21 February 1950 in San Francisco. She obtained a BA (Bachelor of art) before obtaining her Master's degree. She taught at the universities of Leeds, Rochester (New York), California and Colombia. And moved with her family to Goleta in 1981.

In 1983, Wolff began working in the field of vocational rehabilitation, which consists in helping the handicapped by providing professional services such as vocational guidance to ensure suitable work for the handicapped to help them cope with the conditions of life, helping the handicapped in adapting to the demands of the family and society, working on reducing the social and economic burdens and facilitating their integration into the community in which they live. In 1987, she started her own business and owned offices in Santa Barbara and Santa Maria. Wolff had worked in this field for more than 20 years and earned a reputation as an effective and compassionate consultant who had helped hundreds of people return to work.

Wolff began her career in the public service in 1993 when she was elected to the board of directors of Goleta, then she was elected to the Board of Supervisors in 2006 and reelected [1].

Janet Wolff was a professor of cultural sociology and became Director of the Interdisciplinary Research Center related to the University of Manchester in 2006, and was a founding director of the Center for Cultural Studies at the University of Leeds, as well as a director of the $\mathrm{PhD}$ program in visual arts and cultural studies at the University of 
Rochester, New York (1991-2001). She was Assistant Dean for Academic Affairs at Columbia Law School (2001-2006) [2].

Wolff was retired from the university in July 2010 and converted to non-academic writing.

She had written in the fields of sociology, arts, culture, feminism and the arts of the early twentieth century (visual arts and arts related to beauty and sensibility). She had written six books in the field of fine arts, sociology of art, culture and feminist aesthetics. Also, she wrote about 49 articles on feminist aesthetics and the sociology of art. She had recently completed a book, Austerity Baby, which combines memoir, family history and cultural criticism. It was published by Manchester University Press in Spring 2017. [3]

\section{Janet Wolff's Best Sellers}

Wolff has written many books, including:

1. Hermeneutic Philosophy and the Sociology of Art (1975).

2. Aesthetics and the Sociology of Art (1981).

3. The second edition of it was published with the new title, The Social Production of Art (1993).

4. Feminine sentences: Essays on Women and Culture (1995).

5. Anglo Modern: Painting and Modernity in Britain and the United States (2003).

6. The Aesthetics of Uncertainty (2008).

7. Austerity Baby (2017)

She had co-edited (with Mike Savage) a book on cultural institutions in Manchester - Culture in Manchester: Institutions and Cultural Change Since 1950, and she coedited (with Jackie Stace) a book titled Writing Otherwise: Experiments in Cultural Criticism, both of which were published by Manchester University Press 2013. Besides, she co-authored (with John Seed) the book The Culture of Capital: Art, Power and the Nineteenth-Century Middle Class.

1. Hermeneutic Philosophy and the Sociology of Art

This book is interested in studying the theoretical basis of the sociology of art and literature. In that study, Wolff talked about the shortcomings of any social study of art. She also believed that the only way to eliminate this deficiency was through appropriate attention to art itself by developing a more general theory of art and society, which can be a guide to the researcher facing problems relating to aspects of social life and any aspects of artistic work in documentary content related to their artistic qualities or historical artistic characteristics. So, Wolff felt that there was an urgent need for a perfect theoretical basis for the sociology of art. The sociology of art was one of the important topics that Wolff had focused on in her scientific career and had discussed in more than one book of hers. Therefore, we will discuss the topic of the sociology of art and present Wolff's most important ideas on this subject through the chapters of the thesis. [4]

2. Aesthetics and the Sociology of Art
This book systematically demonstrates that arts can be adequately understood only from a social point of view and argues that art is a composite entity of a number of historical factors. In this book, Wolff refutesand presents opinions, then comments on these views. In this new edition, Wolff argues that the concepts of aesthetics should be saved as far as possible from those who may equate the artistic values with the political value from the overall relative aesthetics which made her unable to judge the artistic values. This book consists of an introduction to the first editionand another introduction to the second edition, six chapters and a list of references. We will analyze and discuss Wolff's ideas and opinions in this book in the final chapter of the thesis. [5]

3. The Social Production of Art

This is an important book for cultural studies and the sociology of art since its first appearance in 1981. It provides a clear and important overview of the theories that contribute to the sociology of art project, from sociology to art history through to literary theory, feminism and media studies. In this book, Wolff bridges the gap between European and American rapprochements to cultural production. In this book, the questions related to the role of the reader, the viewer and the nature of authorship are also dealt with.

This book is also considered a valuable introduction to central issues in the sociology of arts. It also relies on sociology, art history, feminism, literary and media studies, in order to explain the social nature of arts, its production, distribution and independence. The book also discusses changes in sociology and cultural studies, and their impact on the sociology of art project and the issue of cultural policy and its relationship to postmodernism. Wolff also discusses the issue of identity politics concerning gender and race. This book contains a wealth of information on thinking about the past, present and the sociology of art. It is of particular interest to students of the arts and students of sociology.

This book has been published in two editions. This second edition is the result of a review and update of Wolff's ideas and rethinking these issues, taking into account what has been accomplished in cultural studies and the sociology of the arts since the first edition appeared in 1984. The book consists of an introduction, six chapters and a conclusion. [6]

4. Feminine Sentences: Essays on Women and Culture

In this book, Wolff discusses the relationship of women with modern and postmodern culture. It also raises the issue of women's writing and how women begin their own lives and build their identities in a patriarchal culture through the writing process itself. It also makes a convincing defense of the feminist cultural policy, including politics of the body. In this book, "Wolff" talks about literary modernism that describes the experience of men in the world. "Wolff" triesin this study to show that women should not be excluded from cultural forms of knowledge and the media, and that women have a voice that must be respected. As Wolff askes in this book, is there a feminist cultural policy? And she wonders, does the female body represent a site of oppression and appropriation?

This book is major evidence of Wolff's distinguished position, and it is of interest to everyone working in the fields 
of cultural and literary theory, women's studies and sociology. This book consists of an introduction, eight chapters, and a list of references. [7]

5. AngloModern: Painting and modernity in Britain and the United States

"Janet Wolff" asserted in this book that the practice of art in the early twentieth century in Britain and the United States of America had been marginalized by historians and critics, after the emergence of modern art in the Post-Cubism period. In this book, Wolff explores the work that was actually real and metaphorical and investigates the social, political, institutional and aesthetic processes by which this art faded and fell in the post-war period. Through that, she thought that the issues of gender and race played an important role in critical assessments and historical value. For example, Wolff argues that the work of central artists in the development of the Whitney Museum declined to a minor role in the post-war period when "feminine" realism was classified as opposed to the aggressive masculinity of abstract expressionism. "Wolff" discusses how modern art and realist new traditions coexisted in tension in the post-war period, in which modernism claimed superiority over realism at the end of the twentieth century. The book consists of an introduction, six chapters and a list of references. [8]

6. The Aesthetics of Uncertainty (Columbia Themes in Philosophy, Social Criticism, and the Arts)

Several critical rapprochements have undermined traditional concepts of aesthetics in recent decades. Among these rapprochements are feminism and infrastructure, postcolonialism and Marxism. But questions of aesthetic judgment still stand and many critics are now seeking "A return to aesthetics."

In this book, Janet Wolff introduces "post-critical aesthetics" that is based on shared values negotiated within the context of society. She links this approach to contemporary debates about a committed policy that is likewise based on the abandonment of certainty. "The Aesthetics of uncertainty" (which is not relativist) does not provide a discourse about beauty that contemporary critics can engage with, but rather provides a basis for a committed judgment through assigning value to artworks.

In this book, Wolff discusses the issue of beauty concerning feminist criticism, the problematic situation of English art in the 20th century, the visual representation of the Holocaust, Jewish identity as portrayed by artist R. B Kitag, modernism in the 1940s and the nature of attractive thinking in sociology. She deals with the desire for certainty and timing of doubt. It concludes with a reflection on the intersection of aesthetics and ethics, arguing that ethical issues are so involved in aesthetic discourse. The book consists of an introduction, six chapters and a list of references. [9]

\section{Austerity Baby}

This book is an exploratory history, focusing on the Jewish experience in England and Germany during the twentieth century. In this book, Wolff talks about exile and displacement, lives (and deaths), mother-daughter relationships, generational transmission of trauma and experiences, transatlantic reflections, and the struggle for creative expression. The book also includes the stories that were collected and the people who lived them, the arrest of foreigners in Britain during World War II, the cultural life in Rochester, New York in the 1920s, and the social and personal meanings of colors.

"Wolff" also talks about the relationship of Henry Simon from Manchester with the Norwegian explorer Fridtjof Nansen and Eleanor Rathbone, the liberal British activist and parliamentarian in the 1940's. The book also presents reflections on the life and images of geniuses. The book consists of ten chapters and a list of references. [10]

\section{Contemporary Philosophical Trends That Janet Wolff Influenced}

\section{Feminist Philosophy}

The trend of feminism is one of the most prominent currents of present Western thought and contemporary philosophy. Since the early 1980 s, the trend of feminism has reached levels of maturity that is not confined to women's emancipation only but has gone beyond this to study man and his issues in contemporary society. This trend has pushed scholars, philosophers and thinkers to reconsider many of the previous issues and intellectual assumptions that ignored and excluded women as a result of the one-dimensional vision.

Feminist philosophy was established in order to reject the only masculinity proposed for civilization and progress, and therefore feminism is nothing but an ideology for the emancipation of women, as it confirms in all its methods the belief that women suffer from injustice because of males, that men are the center of the universe and women come in a lower status than him that deprives her of the potential for growth and tender only because she is a woman [11].

Feminist philosophy is based on resistance to patriarchy or discrimination bases on sex to express the state of oppression that one group suffers from, so we find that educated women throughout the ages present critical arguments dealing with male domination in various institutions (education, government, science and art).

The feminist appropriation of the concept of autonomy requires a narrative to women who seek to define feminine conditions against patriarchal restrictions that hinder the expression of their obligations and their own senses and their reshaping.

For example, we find "Susan Bryson" writes about regaining self-control over her life after being tragically raped. Patricia Hill Collins also explains the power and importance of self-identification for African and American women fighting the dominant cultural images of themselves as princesses and mothers. Mini Bruce Pratt narrates how she struggles to live as a homosexual while at the same time abandoning racism and anti-Semitism. There are many accounts that embody the struggles of the independent woman [12]. 
"Janet Wolff" was influenced by this ideological trend. "Wolff" believes that the invisibility of women in the history of arts is no longer explained as a result of their shortcomings in photography, composition or music, but rather in the context of the structures of the worlds of music and art that exclude women from training and success through various direct or indirect means. As well as in the context of the topic devoted to the practices of art history and criticism which depend on sex discrimination.

Wolff agrees with Greeleda Pollock that women's art is based on conditions and standards different from men's art. On the one hand, some insist on preserving aesthetic standards by measuring all aesthetic works with a single global standard, especially (local arts and working-class literature) and on the other hand, we find that when it comes to women, especially feminine art, it uses different conditions and criteria.

"Wolff" believes that when evaluating artworks, sexual considerations intervene in the search for discrimination, and this is evident in the case of the painting by artist "David Sherlock in Ony Valley" displayed in the "Metropolitan Museum" in New York. When it was realized that it was a woman who drew her and her name was "Constance Marie Charpentier", the economic and monetary value of the painting fell [13].

Wolff believes that historians of feminist art have provided evidence that gender issues have interfered with judgments that claim to be related to the aesthetic. What Rosica Parker presented on the social history of embroidery explains to us how embroidery was practiced by men in the past as an activity that gives great prestige, and over time it has become associated with women and housework in the eighteenth century, which led to its separation from the arts and depreciate it be considering it as just a hobby practiced to occupy leisure time. [14]

Wolff believes that "postmodernism" has provided the opportunity for women to express themselves by discovering their critical and emancipatory potentials. In addition, it enables them to write novels and discourses to express their experience and establish their active and heard presence in society.

Wolff says that the "History of Feminist Art," which is an important contribution and review of the sociology of art, has raised questions about the elimination of women from writing art history. For example, the artist "Lee Criens", who married "Jackson Lowock" and whose work recently appeared, was deleted. It is the technical methods that Crean's research is about are what resulted from the institutional differentiation (1). [15]

There is no doubt that the concern for women and their issues was an effect of postmodernism. The women's movements have adopted the principle of the conflict between the sexes and called for a revolution on customs and traditions that make attention and focus on the experiences of men in all fields of life without the experience of women, and even limiting the experience of women within the boundaries of the family, home and raising children. Over time, women's movements became a major political force that has spread across America and Europe. Women's movements developed in different directions so radical feminism, liberal feminism and Marxist feminism have emerged.

In this chapter, we will talk about the trend of radical feminism, which is the direction that Janet Wolf has been influenced by. Wolff is considered one of the moderate feminists who see the importance of the role of women alongside men to participate in building a better society. Wolf adopted the trend of radical feminism with its moderate direction which believes that the real problem is patriarchy, which is a complete system that strengthens the authority of men over women and children in the family. Therefore, radical feminism is based on studying the nature of family relationships. It believes that the family is the main place where women get oppressed, as it described the family as a patriarchal unit within a complete patriarchal entity between the individual and the social formation. Therefore, moderate radicalism seeks to demolish patriarchal authority, overthrow male centralism and affirm femininity on the side of masculinity in civilized structures, not to replace feminine centralism. It is necessary to balance the two sides and to work to develop traditional institutions in a way that eliminates injustice against women. [16]

In her book, Feminine sentences, Wolff says that she wanted to refer to the secondary meaning of the word "sentence," which indicates an exploration of the limitations that women suffer from in a patriarchal culture, and that women in this sense are condemned to containment and silence. Most importantly, the purpose of this book is to contribute to the omission of that "sentence". And in the process in which women find ways to intervene in an excluded culture and to clarify their own experiences. And feminine sentences are those forms and expressions in a variety of cultural and media forms of a woman's voice. [17]

Therefore, we find that "Wolff" was interested in social sciences by virtue of her specialization as a sociologist, and she combined her study of social sciences with feminism and discussion of women's issues. And this is what Wolff focused on and discussed in most of her books of a feminist social characterin an attempt to advance and raise the role of women in the family. It focused on social formations because it considers the basis for women's exposure to male oppression and discrimination.

The meaning of the word "راديكالية-Radicaleh" is an Arabization of the English word Radicalism, whose origin is the word Radical. It stems from the Latin word "Radix" and the word "جذر-jazar" corresponds to it in the Arabic language according to the literal meaning, and it generally refers to the goal-oriented direction for the radical and complete change of the social and economic reality. Among the most prominent radical feminists, there are Andrea Dworkin, Audre Lorde, Angela Davis, Catharine A. MacKinnon, Kate Millett, and Shulamith Firestone. [18]

Radical feminism is the product of the second wave of feminism in the West. It has appeared in the twentieth century. Feminism in that century wanted to be deeper as it wanted to 
be radical feminism. Angela Davis says that Radicalism simply means understanding things from the roots. Radical feminism saw the oppression of women as the basis and root of all forms of oppression known to humanity (1). In order to know more about radical feminism, it is necessary to clarify the difference between the trend of libertarian radicalism and cultural or civilizational radicalism:

\section{Libertarian Radicalism}

This trend calls for the necessity of eliminating the family because it is the main source of women's oppression due to the inequality between men and women within the family, linking all family matters to women, and even restricting the role of women to raising children and even restricting the role of women in raising children and taking care of the home. Therefore, libertarian radicalism called for the necessity of destroying the sanctity of the family. Juliet Michel saw that the family is a cultural condition, not natural, and that the function of the Masculinity ideology makes it natural. Therefore, libertarian radicalism seeks to amend and develop this situation by making the family a place for participation between men and women. [19]

Radical feminism is based on biological conditions, but not in the traditional sense that makes women inferior to men but it is based on a biological basis that represents the privacy of the woman and confirms her distinction from men and may be superior to him in her distinction and uniqueness of the ability to reproduce. It also confirms that the woman is not the most beautiful being, as some claim, but she is the most elegant and capable as well. [20]

However, we see that with the development of women's liberation movements and trends, shateh trends appeared in their ideas. Thus a shateh trend appeared within the movement of liberal radicalism that sees feminine centrality as opposed to male centralism, by giving women unlawful rights such as their right to abortion, that childbearing is a cause to women's slavery, and that they have rights outside the family based on individualism prevailing in American civilization, in addition to her right to practice lesbianism.

They saw lesbians as truly feminists who could challenge and confront male domination. Homosexuality and the lesbian family formed the model for the new family. In the 1970s, radical feminist Joanna Ross called for women to be freed from the burdens of pregnancy and childbirth. Her works embodied a dream about the complete disposal of patriarchal male society. Proponents of this trend also defended pornography as art that expresses the extent of oppression and violence to which women are exposed. [21]

\section{Radical cultural or civilizational feminism}

It means that feminism has acquired an intellectual maturity and has become searching for a deeper and more comprehensive theoretical framework than merely demanding equality with men. Rather, it saw that women must rediscover themselves as women, their suppressed souls, and work to show their positivity, then formulate a theory that expresses the feminine identity. Femininity has been an advanced stage concerned with self-discovery and the projection of femininity to achieve a kind of balance for humanity. [22]

Thus, we see that the true radicalism of twentieth-century feminism is developing day by day to confirm the feminist vision that has long been marginalized.

\section{Marxism}

Marxism is a scientific theory that consists of a set of laws, categories and hypotheses with a methodology that is a tool for the detection and analysis of social phenomena. Every Marxist is supposed to follow, in a rational, exploratory and critical spirit all developments and social conflicts to present visions, programs and mechanisms of action aimed at changing and overcoming the reality governed by the exploiting classes. Every Marxist is supposed to follow, in a rational, exploratory and critical spirit all developments and social conflicts to present visions, programs and mechanisms of action aimed at changing and overcoming the reality governed by the exploiting classes.

Karl Marx laid the foundation stone in the dialectical materialist approach that aims to develop Marxist theory in order to guide life practice. Marxist epistemology is part of the process of life movement and its variables that never stagnate or stop. Marxism refuses to deal with closed intellectual structures but rather deals with intellectual structures that always develop with the development of scientific achievements and discoveries in all areas of life and its new facts. Marxism refuses to limit itself to a closed systematic framework or to specific historical circumstances. [23]

Janet Wolff had been influenced by Marxism and took it as a basis in presenting her social ideas. In Wolff's view, art should not be linked to class or ideology. She believes that there is excessive bias by those in charge of distributing grants, in addition to the fact that official standards do not take popular art into account and do not recognize works produced outside the mainstream in literature or art in the world, such as biographies and writings of the working class published by the National Writers Union. Wolf says that there are vague, non-critical concepts and biased methods when assessing the value of a work or serious writing, which results in preferring some writers over others, and this is against the principles of Marxism that Wolff adopts. [24]

With the emergence of the new Left and its emphasis on overcoming the idea of class struggle based on the nature of production relations in society and considering the working class as an essential structure in society. The "New Left" also focused on marginalized groups in society that are subject to the domination of the global capitalism in the struggle, such as classes of sex, color and race.

Undoubtedly, the development of "Marxism" was an important matter in the history of art, as Marxism has influenced the history of art in the modern era, so "bourgeois society" has become one of the familiar terms that constitute the lexicon of ideas for those who practice the social history of art in its various forms. It is necessary to remember the role of "neo-Marxism" in the development of the so-called new art history. Marxism talks about the social history of the position of art, and the term "social history of art" benefited 
from the interest in theoretical issues in the twentieth century. And "Wolff" was one of those interested in the social history of art. Wolff believes that the social history of the arts has presented some important findings to the philosophy of art. For example, it deals with the arts from the perspective of social history. The social history of art also shows that certain forms of artistic ingenuity have accidentally acquired this quality without being singled out by the functional characteristics that distinguish them from crafts. Wolff believes that aesthetics is a rational practice with a history, as it deals with the artworks of specific groups in certain social conditions. Many aesthetic historians add works of popular culture such as jazz or serious cinema with aesthetic themes worth considering. "Wolff" believes that aesthetics and sociologists have merged with each other in terms of their interests and contributions, which are in the social and historical context of the arts and in the conditions of its production. Both groups have come to undermine the myth of art and expose the myth of the artist's genius (meaning that the artist is the basis as he is the maker of art). And this through two things: first: the historical specificity of the existence of both art and the artist, and second: the interpretation of beliefs and tendencies involved in the production and evaluation of art [25]

Through the foregoing, it becomes clear to the researcher that "Wolff" was influenced by the New Left and its intellectual premises which were taken as a basis in presenting her social ideas. These ideas were taken up by "Wolff" as a basic structure of their ideas, as the new Marxism, in its new concept, is the basis on which she based in its writings.

\section{Postmodernism}

A new term has appeared in the 1980s, which is "postmodernism". As Jameson said: Postmodernism is a pattern of thought with distinct characteristics and a chronological function that links the emergence of a new type of social life and a new economic system. [26]

We should differentiate between the term "postmodernism", which refers to a type of contemporary culture, and "postmodernization" as a period of time that the West has gone through as a result of some of the changes that have followed the process of industrialization and production, and its connection with the growth and inflation of global capitalist organizations. Postmodernism refers to the historical period or time period but Postmodernity is a method or a way of thinking, or the intellectual or cultural movement that has emerged from this historical situation which is called "postmodernization". [27]

The writer "Ihab Hassan" believes that the term "postmodernism" originated in the field of literary criticism, and then was employed in other fields of knowledge such as philosophy, sociology, politics, psychoanalysis, linguistics and religion. "Ihab Hassan" suggests that the term has acquired a meaning in the book of the English philosopher of history "Arnold Toynbee" The Study of History, when he used it to refer to three characteristics of postmodernism that he saw that they distinguished Western thought and society in the middle of the twentieth century, which are rationalism, anarchism and Anomie.

And because of disappearing of the bourgeoisie in controlling the development of Western capitalism since the end of the nineteenth century and the replacement of the industrial working class, which he thought that it was the decline of traditional bourgeois values. [28]

\section{The Relationship of Modernity to Postmodernity}

There are two trends: a trend that sees postmodernism as a break with the modernist project and as a revolution against it, and this trend sees that postmodernism adopts an approach that denies modernism and declares rejection of all its principles, and another trend that sees postmodernism as a kind of crisis within modernism and that postmodernism criticizes modernism and its concepts and tries to develop it in line with the requirements of the new era. [29]

"Janet Wolff" supported the first approach. This trend criticizes the concepts of the classical age and criticizes the established facts. It is based on the criticism of modernist discourse that adopts principles based on oneness, the feeling of possessing certainty, patriarchal authority in all its forms and the forms of authority produced by capitalist society, such as instrumental reason and logos. Wolff agreed with those who reject a narrower definition of modernism that excludes women's work. Most of what women wrote in the nineteenth and early twentieth centuries was related to their experiences in this era, which were very different from those of men. Women used to work in the fields of literature and art, but their works were evaluated according to different criteria by the modernists, while the works of modern men were recognized works.

Wolff says that in the mid-nineteenth century it must be made clear that women were confined to the domestic sphere, the problematic nature of their appearance in the public sphere, and the consequent importance of most of the modern literature (both socially and literally). [30]

Wolff criticized modernist art that did not give up the search for stability. Modernist art is fully concerned with form and believes that form is the source of beauty and that art is neither a simulation nor an introduction to life, but rather a mental product that aims only to enjoyment. Modernist art aims to concern with pure form and rejects realism and objectivity in art, and this is what Wolff rejects. Wolff believes that artworks are produced by certain groups in certain social conditions.

There are two important features that distinguish modernist art at the end of the nineteenth century, the first: the artist's self-awareness of his art as an art and not an employee to serve something, and the second feature: this awareness has pushed the artist to more individualism and subjectivity and try to create his own style that distinguishes him From other artists, whether contemporary or previous to him. The artistic heritage has become a burden on the artist 
and a part of the outside world seeking to free himself from it and producing his art in isolation from it. Thus, the style becomes a means of asserting the self against the world and a product of the self. This violent rebellion against the world has intensified with Oscarwilde's saying, "It is nature that imitates the artist, not the other way around," which led to the difficulty of the language of art and the inability of many to understand it. Thus, modernist art became unpopular art (away from people) and transformed into elite art (which is the select few who have sufficient culture and awareness of the history and development of art) [31]. This is what Wolff rejects, as she believes that the artist (a man or a woman) cannot live in isolation from his social or historical reality and that the artworks are a social product. The artist, through his art, can criticize his reality which he lives, and thus the artist becomes a part of society and not isolated from it, and art becomes accessible to everyone and expresses people and is not restricted to a particular class [32]

\section{Characteristics of Postmodern Arts}

1) Eliminating the boundaries between elite culture and popular culture

Art in this era is not the monopoly of a particular class but is available to everyone. The superficial and the profound in postmodern view are two words used for class distinction. Wolff thought that many aesthetic historians use works from popular cultures such as jazz or serious cinema with aesthetic themes worth thinking about, and that they did not separate popular culture from elite culture but tried to combine them to produce art that everyone would enjoy.

2) Thought of art as a commodity

This is what the modernists tried to avoid, but postmodernism has been able to extend the power of the market (capital) so that it has become the main guide for art by all standards. So we have "market realism" as an alternative to "socialist realism", which has become a restriction imposed on us to deal with it as a sacred commodity of self-contained (2). [33]

3) Connection to Technology

Technology has added to the arts a kind of limitless dazzling without the presence of real objective art, and the recipient is looking for dazzling in everything he sees or reads, Vogel says that the spectator enters the cinema with eagerness and enthusiasm preparing himself to surrender and accept what will happen, and if he finds out that the film is bad and that the delusion did not happen, then he becomes very upset. "Vogel" linked the quality of the artwork with its ability to dazzle, which has become popular at the level of art in its various forms. Technology has now replaced art by creating what is called "virtual reality" that was exclusive to art, and technology creates it, but more impressively. [34]

"Wolff" disagreed with "Vogel" on this point because the judgment about the quality of the artwork, whether it is a novel, painting or other artwork, is not due to the people's admiration for it or that this work met with a positive response from the public. There are criteria for evaluating the artwork that should be taken into account and to maintain the privacy of the artwork.

4) Back to the past

It is a strongly present feature of most postmodern artwork. Postmodernity does not reject the past, but rather re-employs it and produces it in a way that may appear distorted to some people. But it wants to emphasize the democratic spirit with which it deals with heritage, in an attempt to erase the aura that was surrounding famous heritage works. Wolff says in this regard that works such as "Beethoven's Quartet", "Middlemarch", Vermeer's painting "The Music Lesson" and "Chartres Cathedral" in France are a succession of events and historical facts that were evaluated according to agreed social criteria. Also, "Lukács" believes that going back to the past and studying history helps us to understand the nature of societies and their unveiling. And some believe that returning to the past is a result of the weak creative energies and the artist's inability to produce what is new. [35]

\section{The Conclusion}

In the end, we would like to emphasize that the sociologist "Janet Wolff" was able to prove that women can succeed and influence society through her writings and articles. She became one of the educated feminists who was able to present critical arguments to respond to male domination and assert the autonomy of women.

Janet Wolf had proven that the socialization and physiological characteristics of women are all invalid arguments made by racists to depreciate women and deprive them of opportunities.

Janet Wolff is one of the feminists, and there are many other feminists and non-feminists who have tried to put women in the place they deserve and to regain their prestige in all fields.

We can say that Janet Wolff had presented a new vision for the concept of feminist aesthetics. She also tried to clarify the relationship between aesthetics and sociology and the extent of their influence on the other, and their connection to each other to establish a new aesthetic theory in which women play a major role.

Wolff's contributions have paved the way for many women to delve into life and prove that women can compete with men. Wolff is a good example of that.

\section{References}

[1] Al Sotkins, Suzan, Ruwaida, Meriza, Martarodjos, I present to you the feminist movement - translated by Jamal Al Jaziri, Presented by Imam Abdel Fattah Emam, vol. 1, p. 135.

[2] Eggleton, Tree, 1996, Postmodern Illusions, translated by Menislam, Academy of Arts, Cairo, p. 7.

[3] Gamble, Sarah, Feminist and Beyond Feminist, translated by Ahmad Al-Shami, MS, p. 80.

[4] Garaudy, Rouge, 1959, Visbel Raisa al-Raisa'a, translated by Jalal al-Matraji, Dar al-Adab, Beirut, Lebanon, p. 180. 
[5] Grimshaw, Jean, 1986, feminist philosophers-women's perspective on philosophical traditions-wheatsheaf-bringhtonp. 148.

[6] Hemingway, Andrew, (summer, 1996), Marxism and Art History after the Fall of Communism, Art Journal, pp. 20-28.

[7] Hassan, Ihab, 1987, The Turn of Postmodernism, translated by Muhammad Saeed Ibrahim, Dar Al-Hilal Publishing, p. 97.

[8] Harvey, David, 2005, The Case of Postmodernity (A Study of the Origins of Cultural Change), translated by Muhammadiyah, Center for Arab Unity Studies, Beirut, p. 145.

[9] Jenshifford, Linda, 2004, The Feminism of Science, translation of Yemen's Tarif al-Khuli, the World of Knowledge 2004, p. 11.

[10] Mustafa, Badr al-Din, 2013, the case of postmodernism (philosophy and art), first edition - The General Organization of Cultural Palaces - Cairo - p. 68.

[11] Mullerrauken, Susan, Women in Western Political Thought, translated by Imam Abdel fattah Imam - p. 234.

[12] Risberg, Nicholas, 2002, Postmodern trends, translated by Najershwan, The Supreme Council for Culture, Cairo, 2002, p. 23.

[13] Sterling, Kristin, 2002, Cultural Studies Expert Janet Wolff Named School Of the Arts Associate Dean for Academic Affairs, articalin journal.

[14] Tarif, Yemen, 2014, Feminism and the Philosophy of Science, The Public Authority for Cultural Palaces, Cairo, 2014, p. 48.

[15] Tolba, Brahim, 2008, Feminist Philosophy, Dar Al-Mostafil for Publishing and Distribution, Tanta, p. 63.

[16] Wolf, Janet, 2000, Aesthetics and Sociology of Art, translated by Maritriz Abd al-Masih, Khaled Hassan, Revision by Maritriz Abd al-Masih - The Supreme Council of Culture - pp. 3: 276.

[17] Walff, Jannetx, 1997, Hermeneutic philosophy and the sociology of art, Routel de library editions: contintal philosophy, p. 3.
[18] Walff, Jannet, 1993, Aesthetics and the sociology of artlondon, George allen \& unwin-boston--p. 2-3.

[19] Walff, Jannet, 1990, feminine sentences: Essays on women and culture-united kingdom-December 28, 1990-P. 2.

[20] Walff, Jannet, 2003, Anglomodern (painting and modernity in Britain and unitedstates), cornell university press, London, p. 2, 192, 200, 209.

[21] Walff, Jannet, 2008, The Aeathetics of uncertainty (Columbia Themes in Philosophy sicialcritism, and thearts), Columbia University Press, USA, p. 3.

[22] Walff, Jannet, 2017, Austerity Baby, Manchester university press, Manchester, united kingdom, p. 2-3.

[23] Wilson Elizabeth, 1983, what is to be done about violence against women-penguin-harmonds worth-p. 178.

[24] Walff, Jannet, 2008, The Aeathetics of uncertainty (Columbia Themesin Philosophy sicialcritism, and thearts), Columbia University Press, USA, p. 89.

[25] https://www.countyofsb.org/bos/wolf/biography.sbc.3mars, 22april, 2018, 12:00pm.

[26] www.viscult.ehu.It-postedon20jan, 2018, 10:30.

[27] https://www.britannica.com/topic/communism4-8-2019, 10:30am.

[28] Hasan, Ehab, 1987, p. 97.

[29] Harve, David, 2005, p. 145.

[30] Walff, Jannet, 1990, p 209.

[31] Claire, Jonathan, 2005, p. 89.

[32] Walf, janet, 2000, p. 90.

[33] Waugh, Patricia, Cambridge, Encyclodia, Literary, Criticism, Issues 9, 427.

[34] Risberg, Nicholas, 2002, p. 23.

[35] Wolf, Janet, 2000, p. 140. 